DOI: 10.38014/ehs-ss.2019.4.12

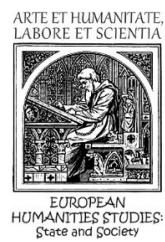

\title{
Лариса ПШЕМІНСЬКА
}

\section{Принципи музично-педагогічної діядьності М. Д. Деонтовича у Тульчинському державному хорі (1920-1921 pp.)}

Постановка проблеми. Українське суспільство 3 багатьох причин (економічних, фінансових, кадрових і т. ін.) зіткнулося 3 новою ситуацією в освіті. Постало питання про необхідність змін умов, форм, методів навчання і виховання (особливо в професійній сфері), почався інтенсивний пошук сучасних педагогічних прийомів, адекватних часу і тенденціям в освітньому європейському просторі. Традиції української музичної педагогіки задишаються на сьогоднішній день досить міцними, зберігаючи свою життєздатність і актуальність завдяки високій духовності, відданості гуманістичним цінностям, дотриманню національних, етичних і естетичних ідеалів. Поглиблений аналіз практики вокально-хорового навчання i виховання свідчить про те, що педагоги нечасто звертаються до цих традицій, або реалізують їх в недостатній мірі. Все це обумовлює 


\section{EUROPEAN HUMANITIES STUDIES: State and Society}

актуальність звернення до спадщини великого українського педагогамузиканта, хорового диригента і композитора М. Д. Деонтовича.

Основними положеннями, що визначають сутність, зміст, провідні вимоги до сучасної мистецької освіти є принципи. Вони, як основні положення мистецького навчання, визначають сутність, зміст, провідні вимоги до взаємодії вчителя та учнів. Більшість принципів мають широке узагальнююче значення, тому в теорії та практиці педагогіки проходить процес постійних пошуків і уточнення принципових положень, які, за визначенням О. Рудницької, можуть спрямовувати діяльність педагога у конкретних навчадьно-виховних ситуаціях [15, с.85].

Мета статті полягає у висвітленні музично-педагогічної діяльності М. Деонтовича у Тульчинському державному хорі, виявленні основних формам організації музичного навчання й виховання, аналізі методичних прийомів, виокремленні основних принципів роботи з даним аматорським колективом.

Аналіз основних досліджень і публікацій. Дослідницький інтерес до мистецько-педагогічної діядьності М. Деонтовича є постійним та різноманітним. Життєвий, творчий та педагогічний шлях композитора висвітлено у монографії А. Завальнюка [8]. В наукових розвідках музикознавців та композиторів Н. ГерасимовоїПерсидської [2], М. Гордійчука [3], Н. Горюхіної [4], В. Дяченка [7], П. Козицького [22], С. Орфеєва [14], $\lambda$. Семенко [18] та ін. висвітлено музичну мову М. Деонтовича, проаналізовано особливості поліфоніі, гармонії, форми творів митця, розкрито жанрові особливості хорових обробок. Грунтовний аналіз підручників композитора здійснив В. Черкасов [20]. Краєзнавці Вінниччини Г. Зельд [9], О. Іовса [10], М. Недобой [13], В. Святелик [16;17] досліджували історію Тульчинської хорової капели, яку створив М. Деонтович. Однак, вектори музичнопедагогічної діяльності керівника в роботі з означеним колективом у 1920-1921рр. дослідниками не висвітлено і потребують детального вивчення, аналізу та впровадження в сучасному хоровому мистецтві.

Виклад основного матеріалу. Управдіння хором - одна із найскладніших та багатогранних музичних спеціальностей, яка вимагає від диригента не тільки грунтовної музично-теоретичної підготовки, уміння читати хорову партитуру та володіння прийомами диригентської техніки, а і фахової спрямованості, в основі якої лежить потреба в педагогічній діяльності. Вона вкдючає в себе: педагогічний такт, вимогдивість, наполегливість, витримку, 
психодого-педагогічну пильність і спостереждивість, педагогічну уяву, творчий підхід щодо інтерпретації хорового твору, прагнення до педагогічного вдосконалення.

3 точки зору педагогічної та громадської діядьності М. Аеонтовича науковці вважають найбільш плідним період роботи митця у Києві в 1919 році. Однак через складні політичні події в країні композитор змушений був повернутися до родини у Тульчин. Иого здоров' я його було підірвано, морадьний стан - важкий, бо робота у провінційному містечку не обіцяла такого розмаху як у столиці [3;7;16].

Щоб підтримати родину у важкий період матеріальних нестатків М. Леонтович викладав у трудовій школі, давав приватні уроки, відкрив першу у Тульчині музичну школу (20 листопада 1920 р.), керував церковними хорами, у дислокованих частинах Червоної Армії організовував солдатські хори. Із запису у журналі вихідних паперів, дізнаємося «про направлення М. Деонтовичу припису (з 1 серпня 1920р.) зайняти посаду завідувача секцією мистецтв при Брацлавському повітовому віддіяі народної освіти» [5].

У вересні 1920 року М. Леонтович створив перший державний аматорський хор в м. Тульчині. Про прийом його на посаду керівника державного хору зазначено у Сповіщенні про щотижневий звіт Тульчинського відділу народної освіти від 11. 09. 1920 р.. Завідуючий наросвітою М. Доброгаєв 18 вересня 1920 року повідомляв про роботу позашкільного відділу, куди входила секція мистецтв, керована М. Деонтовичем та про діяльність у Тульчині державного хору [6]. Організація державного хору для Миколи Дмитровича була працею нескладною, оскільки він керував церковним хором, співав в обох церквах Тульчина (Успенській та у Великому соборі). 31920 року усі церковні хори почали реорганізовувати у державні [16, с. 22]. Тому відбір хористів він почав саме із церковних хорів.

До складу нового колективу увійшли усі верстви населення міста різних вікових категорій, любителі хорового співу з відмінними годосами - городяни, соддати місцевого гарнізону. Основою колективу стали учениці єпархіального жіночого училища, в якому М. Аеонтович працював з 1908 по 1918 рр. Перші хористи - брат і сестра Анатолій і Марія Брадучан, А. Брень, Л. Гамбицька, Я. Грех, Є. Доброгаєва, Б. Перетятко, К. Сокович, Т. Сокович, М. Тоган, Ф. Христофович, Н. Снегурська, М. Сувчинський, В. Шаравська, $\Lambda$. Максимович, Х. Аотоцький, М. Покровський, якийу майбутньому став послідовником свого Учителя, професором Одеської консерваторії, 


\section{EUROPEAN HUMANITIES STUDIES: State and Society}

годовним диригентом Одеського оперного театру, отримав звання заслуженого артиста УРСР та багато інших. Співаків налічувалося біля 60 осіб. Хор був мішаний чотирьохголосий (сопрано, альти, тенори і баси). Відомо, що партію сопрано виконувади сестри Євгенія та Юлія Корнич, Катерина та Тетяна Соковичі; альтів - колегивчителі Є. Доброгаєва, Д. Гамбицька, Д. Максимович, Н. Снегурська, В. Шаравська; тенорів - А. Брень, А. Губнюк, М. Сувчинський; басів - Х. Лотоцький, Я. Грех та інші [9].

Заняття зведеного хору відбувадися в будинку кодишнього духовного учидища тричі на тиждень, проте роботу по партіям керівник проводив в окремому приміщенні. За спогадами $\Lambda$. Грабовецької дізнаємося, що «в ті часи Микола Дмитрович жив і працював на повну силу. Крім музичної школи, він організував свою капелу в Тульчині, провадив співанки у приміщенні споживспілки, куди треба було бігти за два кілометри...» [12, с. 44].

Основними формами організації музичного навчання й виховання в роботі М. Деонтовича 3 Тульчинським державним хором були практичні заняття та концертні виступи. Завдяки ним педагог здійснював розвиток здібностей хористів, виховував їхні особисті якості, формував основи їхньої музичної культури. Годовною метою цих занять було виховання в учасників колективу інтересу до хорового мистецтва та української народної пісні. 3 правидьним підходом та послідовністю методичних прийомів М. Аеонтович умів впливати на індивідуадьний розвиток кожного учасника хору, використовуючи словесні методи навчання (пояснення, бесіди (репродуктивну, евристичну), повідомлення, повторення, дискусіі) та наоно-слухові методи навчання (диригування, виконання музики учасниками колективу хоровий спів, а також особистий приклад виконання кожної партії хору). Так як основою хору були вихованки Тульчинського жіночого єпархіального учидища та вчителі шкіл, які добре знали музичну грамоту, то М. Деонтович практикував з ними на репетиціях спів по нотам, таким чином використовуючи й наочно-зоровий метод.

Досягнення високої якості у хоровому виконанні (чисте інтонування, організація структурно-ритмічної сторони виконання, робота над темпом і динамікою, дикцією, фразуванням, передачею ідеї та змісту твору і т. ін.) вимагало від М. Аеонтовича серйозної попередньої роботи над музичним матеріалом і подолання чималих технічних труднощів. Учень М. Леонтовича Г. Гриневич зазначає, що «як керівник капели він приділяв багато уваги дикції, вимагаючи, 
щоб «не жували вату» і вимовляли слова як найвиразніше, але співали, не декламували... Диригував спокійно, скупими жестами; коли щось було не до ладу, спиняв хор - закривав обличчя руками, хитав головою» [12, с.111-112].

Є. Карагіна звертає увагу на вміння М. Деонтовича досягти особливого хорового звучання та нюансування: «Зовсім поособливому керував Микола Дмитрович хором - звук у нього був кришталевий. Він дбайливо стежив за звучанням кожного голосу, не даючи йому грубо виділятись..., добивався відмінного нюансування» $[12$, c. 51].

М. Покровський пригадуе, що «Микола Дмитрович розучував партії окремо 3 кожною хоровою групою - сопрано, альтами, тенорами і басами, часто сам підспівував або використовував для цього скрипку». Зазначає він також «чудову ансамблевість», «стройність і ніжну прозорість голосоведіння», професійно доступний за ритмом та мелодичною основою цікавий, різноманітний репертуар, уміло підібраний М. Деонтовичем, основу якогоскладади українські народні пісні, твори зарубіжних, російських та українських композиторів. Згадує розповіді про авторів творів, які виконувади, та про те, що М. Деонтович дюбив читати тексти хорових творів і аналізувати їх, спонукав учасників хору вдумуватись у поетичний світ кожної пісні, «малювати в уяві» картини, пройматись ними, виразно промовляти слова, торкався питань поведінки хористів на сцені [12, с.109-111].

Зі спогадів Ф. Ільніцької дізнаємося, що «..диисципліна в хорі була сувора, образцова. Оскільки ноти в хорі не всі знали, Леонтович наспівував кожну партію і ми по слуху ії вивчали. На співанках розучував мотив 3 кожною партією окремо, і як вже добре мелодія була засвоєна, зводив весь ансамбль хору... Учитель вважав, що хорова партія - це колективний голос, в якому різні тембри повинні здитись в один красивий тембр... [19].

Не дивдячись на те, що хоровий спів а cappella (без інструментального супроводу) є найскладнішим у галузі хорового виконавського мистецтва, більшу частину репертуару колективу складали саме такі твори («Щедрик», «Дударик», «Козака несуть», «Зашуміла ліщинонька», «Зоре моя вечірняя», «Прощай село» та ін.). Тому для М. Аеонтовича було важливо розвивати виконавську культуру, майстерність та художні мождивості співаків. Щоб досягти високих результатів в аматорському колективі, репетиції проводилися часто, а 3 солістами керівник займався індивідуально, бо був твердо перекона- 


\section{EUROPEAN HUMANITIES STUDIES: State and Society}

ний, що техніка хорового співу досягається лише шляхом постійного тренування [1, с. 165].

Композитор невтомно працював над концертними програми, які були побудовані на кращих зразках народнопісенної творчості. Тонко відчуваючи образи української народної пісні, яку він називав «джерелом невичерпної краси» [12, с. 35], Микола Дмитрович прагнув пояснити учасникам хору, що процес виконання народної пісні це завжди переживання, глибоке проникнення в долю головного героя. Пошук сутності поетичного змісту, прагнення виконувати твір, відчуваючи його змістову цінність душею та серцем - стали у педагогічній діяльності М. Леонтовича одним із головних завданням.

Улюбленою обробкою народної пісні М. Деонтовича була «Зашуміла ліщинонька», яку Тульчинська хорова капела включила в першу свою концертну програму. За спогадами А. Дебединця про художню інтерпретацію цієї пісні у процесі розучування дізнаємося про значну увагу керівника капели до аналізу художнього образу твору. "Діщинонька - то є образ сумний у народній поезї. Як і зозуленька. Зозуля кує - то буде горе. Це пісня про кохання. Насамперед треба визначити іï основну думку. Гадаю, що ідея пісні - «перемога». В чому вона проявдяеться? - «А ми таки ходить будем, одне друге дюбить будем». $\mathrm{E}$ тут узагальнений образ дівчиноньки. Ви повинні уявляти собі іiі очі, обличчя, знати хату, де вона живе, i ту завертку в дверях; глечики, які стоять у миснику в хаті...» [12, c. 99]. Працюючи над текстом, М. Леонтович звертав увагу на смислові акценти окремих складів, усвідомлюючи їх як образні характеристики. «...Легше інтонувати сполучення за (за-шу...). Оце шу - глибоке й сумне. 3 цього шелесту здобути $y$. . Аа не виділяти ні в якому разі... Скажіть ці слова, щоб люди заплакади!» [12, с.100].

Вражали хористів диригентська постава Микоди Дмитровича, його пластика рук, виразна міміка. Підтвердженням цьому $є$ спогади Г. Гіньковської, з яких ми дізнаємося, що «...керував Микола Дмитрович хором красиво. Ми розуміли рух його руки. Руки і очі. Ось таким, ладним, зібраним, з витягнутими вперед, трохи піднятими руками і красивою, злегка відкинутою назад головою...» [12, с.36].

Техніка диригування М. Деонтовича базувалася на основі розуміння ним ідейно-художнього змісту кожного музичного твору, який він осмислював в усіх деталях. У результаті чого складався певний комплекс диригентських рухів, який відображав музичний зміст окремої хорової композиції. Його диригентському стилю 
характерні багата тембральність звуку, вміння вибудувати звукову палітру, створити справжні емоційно-образні живі твори-картини.

Таким чином бачимо, що як керівник і диригент хору, М. Леонтович домагався правильного прочитання нотного тексту, професіональної вокалізації твору, чистої, виразної його інтонації, точного хорового строю, злагодженого хорового ансамблю

Висновки. Таким чином, організувавши аматорський народний хоровий колектив, М. Деонтович зумів створити академічний хор, що вирізнявся класичною манерою звукоутворення, складністю репертуару, розвиненістю хорових партій та широтою їх теситурного діапазону.

Отже, музично-педагогічна діядьність М. Деонтовича у Тульчинському державному хорі базувалася на таких принципах:

- принцип систематичного та послідовного навчання та виховання, який реалізовувався через регулярність проведення М. Деонтовичем занять, уміння побудувати роботу над творами від простого до складного, що давало мождивість за невеликій час осягнути значну кількість хорових творів і здійснити ряд концертних програм по селам та містам Поділдя;

- принции доступності втілений через підбір керівником доступного та посидьного д,я виконання репертуару, урахування індивідуальних особливостей учасників (робота по нотами з учасниками, які обізнані з основами музичної грамоти та робота по слуху з учасниками, які не знають нот);

- принщип міциності знань прослідковувався в послідовному накопиченні музичних знань і вмінь через ретельне опрацювання кожного твору та удосконалення вокальнотехнічних і художньо-виконавських навичок для належної підготовки кодективу до виступу;

- принции наочності навчання втілено педагогом через особистий показ музичного матеріалу (інтонування кожної партії хору, демонстрація твору за фортепіано, використання прийомів диригентської техніки, розповідей про художній образ твору, а також виконання музики самими учасниками хорового колективу);

- принции індивідуального підходу здійснювався через використання в процесі репетицій групових та індивідуальних форм роботи 3 окремими партіями; бесід та дискусій 3 учасниками хору; 


\section{EUROPEAN HUMANITIES STUDIES: State and Society}

- принцип активності М. Деонтович застосовував при поясненні емоційно-образного змісту пісні, пододанні завдань високого рівня труднощів як стосовно вибору репертуару, так i виконання художніх і технічних вимог педагога; формуванні і розвитку певних умінь хорового виконавства при співі творів без інструментального супроводу а-сарреlla;

- принцип едності виховання, освіти і розвитку - реалізовувався М. Леонтовичем через використання бесід про музику, фактів біографій видатних майстрів-музикантів, через усвідомлення художньо-естетичного, морального, духовного потенціалу вивчаємого твору, розвиток високих морадьних чеснот виконавців хорового колективу, естетичного смаку шляхом прилучення їх до народної пісні;

- принции зв'язку навчання з життял здійснювався шляхом послідовного розвитку емоційно-ціннісного ставлення до творів музичного мистецтва, світоглядних уявлень, формування естетичної культури особистості, а також використання набутих знань та умінь в подальшій музичнопедагогічній діяльності окремих учасників хору (керівниками хорових колективів стали М. Покровський, Н. Снегурська, Г. Гриневич та ін.);

- принциип народності, культуровідповідності та етнізаціі втілювався М. Леонтовичем через вивчення та виконання різних за жанрами українських народних пісень, виховання любові до рідного слова, звичаїв та обрядів, прищеплення шанобливого ставлення до культури і спадщини українського народу; на основі цього відбувалося й формування національної свідомості, громадянської позиції;

- принции демократизації проявився в духовній співпраці педагога зучасниками творчого процесу на основі шанобдивого ставдення один до одного.

Принципи музично-педагогічної діяльності М. Деонтовича були впроваджені у професійній діяльності його учнями - хоровими диригентами, вчителями співів, композиторами і педагогами I. Годзішевським, Г. Гриневичем, П. Козицьким, А. Дебединцем, О. Міньковським, М. Покровським, Р. Скалецьким та багатьма іншими.

Перспективою подальших пошуків у напрямі представленого дослідження вважаємо педагогічні засади впровадження спадщини М. Леонтовича в сучасну практику мистецької освіти. 


\section{References:}

1. Бенч-Шокало, О. Український хоровий спів: Актуалізація звичаєвої традиції: Навч. посіб. К.: Ред. журн. «Укр.Світ». 2002. 440 с.

2. Герасимова-Персидська Н. Характерні риси поліфонії М. Леонтовича // Творчість М. Леонтовича: Зб. Статей; [упоряд. В. Золочевський]. К.: Музична Україна. 1977. 124 с.

3. Гордійчук М. Микола Леонтович. К.: Муз. Україна. 1972. 55 с.

4. Горюхина Н. Очерки по вопросам музыкального стиля и формы. Київ: Муз. Україна. 1985. 109 с.

5. Державний архів Вінницької області (ДАВО) - Ф.Р-1139: Брацлавский уездный ревком. - Оп.1. - Спр.37. - Арк.33.

6. Державний архів Вінницької області (ДАВО) - Ф.Р-1139: Брациавский уездный ревком. - Оп.1. - Спр.42. - Арк.45.

7. Дяченко В. П. М. Д. Деонтович. 4-е вид. К.: Муз. Україна. 1985. 134 с.

8. Завальнюк А. Микола Леонтович: дослідж., док., иисти: До 125-ї річниці від дня народж. Вінниця: Поділля-2000. 2002. 256 с.

9. Зельд Г. Тульчинська капела ім. М. Леонтовича: про історію створення капели. Червона Тульчинщина. 1927. 24 черв. С.3.

10. Іовса О. Комісар капели: про створення М. Д. Леонтовичем першої української хорової капели. Молодь України. 1967. 13 груд. С.3.

11. Козицький П. Творчість Миколи Деонтовича // Творчість М. Леонтовича. Збірка статей [упоряд. В. Золочевський]. К., 1977. С. 7-16.

12. Микола Леонтович. Спогади. Листи. Матеріали. Упорядкуання, примітки та коментарі кандидата мистецтвознавства В. Ф. Іванова. К.: Музична Україна. 1982. 238 c.

13. Недобой М. Талановитий організатор. Зоря комунізму. 1969. 14 черв. С.5.

14. Орфєєв С. М. Леонтович і українська народна пісня. К.: Муз. Україна. 1981. $75 \mathrm{c}$.

15. Рудницька О. П. Педагогіка: загальна та мистецька: навч. посіб. К.: ТОВ Інтерпроф, 2002. 270 с.

16. Святелик В. Історія Тульчинської хорової капели ім. М. Д. Деонтовича. Тульчин. 1990. 20 с.

17. Святелик В. Слава і загибель. Останній рік життя композитора М. Д. Леонтовича. Тульчин. 2007. 55 с.

18. Семенко Л. І. Їх поєднала пісня Леонтовича...: Нариси з історії муз. життя в Україні 1910-1930-х рр. Вінниця: ПП «Едельвейс і К». 2007. 252 с.

19. Тульчинський краєзнавчий музей. Ф. 110. №8-19. (Анкета Ільніцької Франциски Марцелівни).

20. Черкасов В. Ф. Теорія і методика музичної освіти: [підручник]. Кіровоград: РВВ КДПУ ім. В. Винниченка. 2014. 528 с. 


\section{EUROPEAN HUMANITIES STUDIES: State and Society}

\section{Transliteration of References:}

1. Bench-Shokalo, O. Ukrainskyi khorovyi spiv: Aktualizatsiia zvychaievoi tradytsii: Navch. posib. K.: Red. zhurn. «Ukr.Svit». 2002. 440 s.

2. Herasymova-Persydska, N. Kharakterni rysy polifonii M. Leontovycha // Tvorchist M. Leontovycha: Zb. Statei; [uporiad. V. Zolochevskyi]. K.: Muzychna Ukraina. 1977. 124 c.

3. Hordiichuk, M. Mykola Leontovych. K.: Muz. Ukraina. 1972. 55 s.

4. Horiukhyna, N. Ocherky po voprosam muzykalnoho stylia y formy. Kyiv : Muz. Ukraina. 1985. $109 \mathrm{s.}$

5. Derzhavnyi arkhiv Vinnytskoi oblasti (DAVO) - F.R-1139: Bratslavskyi uezdnyi revkom. - Op.1. - Spr.37. - Ark.33.

6. Derzhavnyi arkhiv Vinnytskoi oblasti (DAVO) - F.R-1139: Bratslavskyi uezdnyi revkom. - Op.1. - Spr.42. - Ark.45.

7. Diachenko, V. P. M. D. Leontovych. 4-e vyd. K.: Muz. Ukraina. 1985. 134 s.

8. Zavalniuk, A. Mykola Leontovych: doslidzh., dok., lysty: Do 125-i richnytsi vid dnia narodzh. Vinnytsia: Podillia-2000. 2002. 256 s.

9. Zeld, H. Tulchynska kapela im. M. Leontovycha: pro istoriiu stvorennia kapely. Chervona Tulchynshchyna. 1927. 24 cherv. S.3.

10. Iovsa, O. Komisar kapely: pro stvorennia M. D. Leontovychem pershoi ukrainskoi khorovoi kapely. Molod Ukrainy. 1967. 13 hrud. S.3.

11. Kozytskyi, P. Tvorchist Mykoly Leontovycha // Tvorchist M. Leontovycha. Zbirka statei [uporiad. V. Zolochevskyi]. K., 1977. S. 7-16.

12. Mykola Leontovych. Spohady. Lysty. Materialy. Uporiadkuannia, prymitky ta komentari kandydata mystetstvoznavstva V. F. Ivanova. K.: Muzychna Ukraina. 1982. $238 \mathrm{~s}$.

13. Nedoboi, M. Talanovytyi orhanizator. Zoria komunizmu. 1969. 14 cherv. S.5.

14. Orfieiev, S. M. Leontovych i ukrainska narodna pisnia. K.: Muz. Ukraina. 1981. $75 \mathrm{~s}$.

15. Rudnytska, O. P. Pedahohika: zahalna ta mystetska: navch. posib. K.: TOV Interprof, 2002. $270 \mathrm{~s}$.

16. Sviatelyk, V. Istoriia Tulchynskoi khorovoi kapely im. M. D. Leontovycha. Tulchyn. 1990. 20 s.

17. Sviatelyk, V. Slava i zahybel. Ostannii rik zhyttia kompozytora M. D. Leontovycha. Tulchyn. 2007. 55 s.

18. Semenko, L. I. Yikh poiednala pisnia Leontovycha...: Narysy z istorii muz. zhyttia v Ukraini 1910-1930-kh rr. Vinnytsia: PP «Edelveis i K». 2007. 252 s.

19. Tulchynskyi kraieznavchyi muzei. F. 110. №8-19. (Anketa Ilnitskoi Frantsysky Martselivny).

20. Cherkasov, V. F. Teoriia i metodyka muzychnoi osvity: [pidruchnyk]. Kirovohrad: RVV KDPU im. V. Vynnychenka. 2014. 528 s. 


\title{
EUROPEJSKIE STUDIA HUMANISTYCZNE: Państwo i Społeczeństwo
}

The Author

\author{
Larisa Przeminska \\ Graduate Student, \\ Pavlo Tychyna Uman State \\ Pedagogical University, \\ Uman, Ukraine \\ E-mail:art_dekanat@meta.ua
}

Abstracts

ПШЕМІНСЬКА ЛАРИСА. Принципи музично-педагогічної діяльності М. Д. Деонтовича у Тудьчинському державному хорі (1920-1921 рр.). У статті розкриваються основоположні засади музично-педагогічної діяльності видатного українського композитора М. Аеонтовича у Тульчинському державному хорі. Акцент зроблено на виявленні основних формам організації музичної освіти, аналізі методичних прийомів, виокремленні принц̧ипів роботи з даним аматорським хоровим колективом, на розкритті особливостей вокально-хорового навчання та індивідуального художнього стилю митияя.

Ключові слова: М. Аеонтович, музично-педагогічна діяльність, Тульчинський державний хор, хорова капела, диригент, педагогічні принциипи.

ПШЕМИНСКАЯ ЛАРИСА. Принципы музыкально-педагогической деятельности М. Д. Деонтовича в Тудьчинском государственном хоре (1920-1921 гг.). В статье раскрываются основополагающие принцииь музыкально-педагогической деятельности вылающегося украинского композитора М. Аеонтовича в Тульчинском государственном хоре. Акцент сделан на выявлении основных форм организации музыкального образования, анализе методических приемов, выделении принцииов работь с хоровым коллективом, на раскрытии особенностей вокально-хорового обучения и индивидуального художественного стиля композитора-педагога.

Ключевые слова: М. Аеонтович, музыкально-педагогическая деятельность, Тульчинский государственный хор, дирижер, педагогические принциипь. 


\section{EUROPEAN HUMANITIES STUDIES: State and Society}

PSHEMINSKAYA LARISA. Principles of music and pedagogical activities of M.D. Leontovych in the Tulchin state choir (1920-1921). The article presents the basic principles of music-pedagogical activity of the prominent Ukrainian composer M. Leontovich in the Tulchin State Choir. It is devoted to the identification of the basic forms of music education organization, the analysis of methodical techniques, the identification of the principles of work with this amateur choir, the disclosure of features of vocal-choral training and individual artistic style of the artist. The scientific reconnaissance was carried out based on the memoirs of the first members of the collective, the materials of the Tulchin Museum of Local History, M. Leontovich's Tulchin House Museum, the funds of the State Archives of Vinnytsia region.

Keywords: M. Leontovich, musical and pedagogical activity, Tulchin State Choir, choir, conductor, pedagogical principles.

PRZEMINSKA ŁARYSA. Zasady działalności muzycznopedagogicznej $M$. Łeontowycza w Państwowym chórze w Tulczynie (1920 - 1921 r.). W artykule przedstawia się główne zasady działalności muzyczno-pedagogicznej wybitnego ukraińskiego kompozytora M. Łeontowycza w Państwowym chórze w Tulczynie. Główny akcent kładziono na wyjawnieniu form głównych organizacji edukacji muzycznej, analizie metodycznych przyjęć, wyróżnianiu zasad pracy z danym amatorskim zespołem chóralnym, na określeniu właściwości nauczania wokalno-chóralnego i indywidualnego stylu artysty

Słowa kluczowe: M. Łeontowycz, działalność muzyczno-pedagogiczna, Państwowy chór w Tulczynie, kapela chóralna, dyrygent, zasady pedagogiczne. 